\title{
Tafsir Indonesia Tentang Penerapan Hukum Allah : Studi Pribumisasi HAMKA terhadap QS. Al-Mā'idah: 44, 45, dan 47 dalam Tafsir Al-Azhar
}

\author{
Oleh: Munawir \\ Email: Munawir.0510@gmail.com / 087839973383
}

IAIN Purwokerto

\begin{abstract}
Abstrak
Penerapan hukum-hukum Allah adalah dua satu isu problematik dalam konteks hubungan antar agama dan negara bagi umat Islam Indonesia. Letak problematiknya adalah, agama (tekstualitas AlQur'an) menyeru umatnya untuk berhukum dengan hukum Allah, akan tetapi negara (sekalipun mayoritas penduduknya beragama Islam) dalam perundangannya justru tidak menggunakan hukum (Syariat) Islam, melainkan UUD 1945. Bagaimanakah HAMKA -sebagai seorang muslim Indonesia- merespon dan menjawab problematika tersebut? Melalui telaah penafsirannya terhadap ayat-ayat penerapan hukum Allah dalam Tafsir al-Azhar, diperoleh jawaban bahwa umat Islam memang, semuanya wajib menerapkan hukum Allah, akan tetapi Indonesia (negara bangsa) adalah bentuk terbaik untuk umat Islam Indonesia. Negara ini menjamin setiap warganya bebas melaksanakan ajaran agama dan kepercayaannya masing-masing, prinsip ini tidak bertentangan dengan spirit hukum Islam 'mendatangkan manfaat dan menolak bahaya'. Dengan ini umat Islam bisa menjadi muslim yang baik, sekaligus menjadi warga negara yang baik pula.
\end{abstract}

Kata Kunci: Tafsir Indonesia, Pribumisasi, dan HAMKA 


\section{PENDAHULUAN}

Tafsir Indonesia adalah unik, dan keunikan tafsir Indonesia tersebut tidak bisa dilepaskan dari keadaan Indonesia; di satu sisi Indonesia adalah negara dengan penduduk muslim terbesar di dunia, tetapi di sisi lain Indonesia adalah negara bangsa dengan UUD 1945 sebagai dasar hukumnya dan Pancasila sebagai dasar negaranya. Indonesia, dalam realitasnya yang seperti itu, adalah inspirasi dunia (baca: negara-negara Islam) karena sampai sekarang Indonesia masih bisa mempertahankan keutuhan dan persatuan bangsa dalam bingkai NKRI. Salah satu kunci dari itu semua adalah umat Islam (sebagai penduduk mayoritas) negeri ini, sudah mampu menyelesaikan problem hubungan antara agama (baca: Islam) dan negara. Mereka tidak lagi terjebak dalam dikotomi; Islam dan nagara (baca: Indonesia). Semua ini tentu tidak bisa lepas dari pemikiran keagamaan para tokoh agama dan ulama terdahulu. Mereka telah berhasil melakukan pribumisasi Islam di Indonesia. Salah satu dari tokoh tersebut adalah Haji Abdul Malik Karim Amrullah, atau yang familier disebut dengan HAMKA. Lewat penafsirannya terhadap ayat-ayat penerapan hukum Allah dalam tafsir Al-Azhar, jelas sekali usaha HAMKA dalam membumikan Islam dalam konteks Indonesia, dan dari sini, umat Islam dunia bisa belajar dari Indonesia tentang bagaimana mendialogkan antara Islam dan negara.

\section{HAMKA DAN TAFSIR AL-AZHAR}

\section{Biografi HAMKA}

HAMKA, sebenarnya adalah nama singkatan dari nama aslinya yang panjang, yaitu Haji Abdul Malik Karim Amrullah. Ia lahir pada tanggal 17 Februari 1908, atau bertepatan dengan tanggal 14 (Ahad malam) Muharram 1326 di Kampung Tanah Sirah, Nagari Sungai 
Batang Maninjau, Minangkabau, Sumatera Barat. ${ }^{1}$ HAMKA -bisa dikatakan berasal dari keturunan 'orang-orang besar' di Sumatera. Moyangnya bernama Syaikh Abdullah Arif adalah seorang ulama besar pelopor gerakan Islam di Minangkabau yang bergelar Tuanku Nan Tuo di Koto Tuo. Datuknya bernama Syaikh Muhammad Amrullâh adalah seorang hafiz al-Qur'an dengan gelar "Fakih Kisai". Ayahnya sendiri yang bernama Syekh Abdul Karim Amrullah adalah juga seorang tokoh terkemuka dan pembaharu di Minangkabau (pelopor gerakan Islam "Kaum Muda" di Minangkabau) yang terkenal dengan julukan "Haji Rasul".

Dari silsilah keturunan orang-orang besar di atas, kiranya tidak aneh kalau HAMKA adalah juga ilmuwan besar yang pernah dimiliki Indonesia. Di antara bukti kebesarannya tersebut adalah banyaknya status keilmuan yang melekat pada dirinya, seperti: sastrawan, budayawan, mubaligh, akademisi, mufassir, sejarawan, bahkan menjadi seorang politikus. ${ }^{3}$ Ia wafat pada tanggal 20 Juli 1981 dalam usia 73 tahun. ${ }^{4}$

\section{Sejarah Tafsir Al-Azhar}

Mengenai sejarah penulisan Tafsir Al-Azhar, pada dasarnya HAMKA tidak bermaksud menuliskan sebuah tafsir sebagaimana yang biasa terjadi di dunia akademik seperti sekarang ini. Sejatinya, Tafsir Al-Azhar adalah kumpulan materi-materi ceramah shubuh HAMKA di Masjid Agung Al-Azhar. ${ }^{5}$ HAMKA tidak bermaksud

1 Dewan Redaksi Ensiklopedi Islam, EnsIklopedi Islam (Jakarta: Ichtiar Baru Van Hoeve, 1993), h.. 75. Lihat juga, HAMKA, Kenang-kenangan Hidup (Jakarta: Bulan Bintang, 1979), h.. 9.

2 Deliar Noer, Gerakan Modern di Indonesia 1900-1942 (Jakarta:LP3ES,1981), h.. 124.

3 Dengan kebesarannya itu, HAMKA juga mendapat Gelar Buya, sebuah gelar kehormatan bagi orang Minangkabau. Kata 'buya' dari bahasa Arab Abi/Abuya yang artinya 'bapakku' atau 'seseorang yang dihormati'. Baidatul Roziqin, 101 Jejak Tokoh Islam Indonesia (Yogyakarta: e-Nusantara, 2009), h.. 188.

4 Dikutip dari Abdul Manan Syafi'i, "Pengaruh Tafsir al-Manar..., h.. 266.

5 Dalam hal ini, HAMKA menjadi penceramah tetap di Masjid tersebut sejak tahun 1959, 
menulis kitab tafsir secara khusus, barangkali hal ini bisa dipahami, karena pada saat itu suasana politik sangat tidak menguntungkan bagi pengembangan pemikiran HAMKA. Dalam konteks ini, pada masa pasca kemerdekaan, tepatnya pada tanggal 27 Januari 1964, ${ }^{6}$ HAMKA dipenjara oleh pemerintahan Demokrasi Terpimpin Soekarno. ${ }^{7}$ Tiga tahun menjalani hidup sebagai pesakitan ini di Sukabumi, justru HAMKA mendapatkan hikmah yang besar, yaitu ia dapat menyelesaikan $30 \mathrm{Juz}$ Tafsir Al-Azhar. ${ }^{8}$

Secara keseluruhan tafsir Al-Azhar terdiri dari 30 juz, sesuai dengan jumlah juz Al-Qur'an itu sendiri. Setiap juz dimulai dengan muqaddimah, dengan diberi judul misalnya "muqaddimah juz 3". Dalam muqaddimah tersebut terdapat ringkasan (abstrak) penafsiran yang akan dibahas.

Adapun langkah sistemik yang digunakan HAMKA dalam dalam Tafsir Al-Azhar adalah: Pertama, HAMKA mengelompokkan beberapa ayat yang berurutan menjadi satu kelompok ayat yang dianggap satu tema. Kedua, kelompok ayat-ayat tersebut kemudian ditafsirkan dengan terlebih dahulu ditetapkan judul yang sesuai dengan kelompok ayat tersebut. ${ }^{9}$ Ketiga, setiap penafsiran selalu diberikan keterangan tentang bagian mana dari suatu ayat yang sedang ditafsirkan, dengan mengulangi kembali potongan terjemahan ayatnya. Setelah itu, baru ia tafsirkan potongan ayat tersebut secara panjang lebar.

yang waktu itu masjid tempat HAMKA menyampaikan ceramah shubuhnya belum diberi nama masjid Al-Azhar. Adapun pemberian nama Al-Azhar adalah dilakukan oleh Grand Syaikh (Rektor Universitas) Al-Azhar Mesir Mahmoud Syaltout pada tahun 1960 saat beliau berkunjung ke Indonesia, dengan harapan semoga masjid tersebut menjadi AlAzhar-nya Indonesia.

6 Ia difitnah dan dituduh telah bergabung dengan komplotan yang ingin membunuh Presiden dan Menteri Agama. Sekalipun untuk tuduhan ini, HAMKA tidak pernah diadili dan tidak terbukti.

7 Abdul Manan Syafi'i, “Pengaruh Tafsir al-Manar..., h.. 265.

8 HAMKA, Doktrin Islam yang Menimbulkan Keberanian dan Kemerdekaan (t.kp.: tp. 1985), h.. 40.

9 Pemberian judul seperti ini, dianggap suatu cara penafsir untuk memberikan informasi awal kepada pembaca tentang pembahasan yang akan dilakukan. 
Dari sejarah pemikiran, Tafsir Al-Azhar banyak dipengaruhi oleh Tafsir Al-Mannar karya Muh. Abduh. ${ }^{10}$ Perjumpaan HAMKA dengan pemikiran tokoh modernis Islam tersebut adalah pada saat ia belajar di Sumatera Thawalib Padang Panjang tahun 1922. Tafsir Surat al-'Asr karya Muh. Abduh menjadi salah satu materi wajib yang diajarkan di madrasah tersebut. Bahkan tafsir Juz 'Amma karya M. Abduh yang sudah diterjemahkan ke dalam bahasa Indonesia juga menjadi salah satu referensi bacaan di lembaga pendidikan ini. Jika dirunut ke belakang, penyebaran gagasan-gagasan pembaharuan Islam M. Abduh ke Indonesia dilakukan oleh para pedagang Arab yang menetap di Indonesia pada abad ke-19. ${ }^{11}$

\section{TEKSTUALITAS AYAT-AYAT PENERAPAN HUKUM ALLAH}

\section{Ayat-ayat Penerapan Hukum Allah}

a. QS. Al-Maidah: 44:

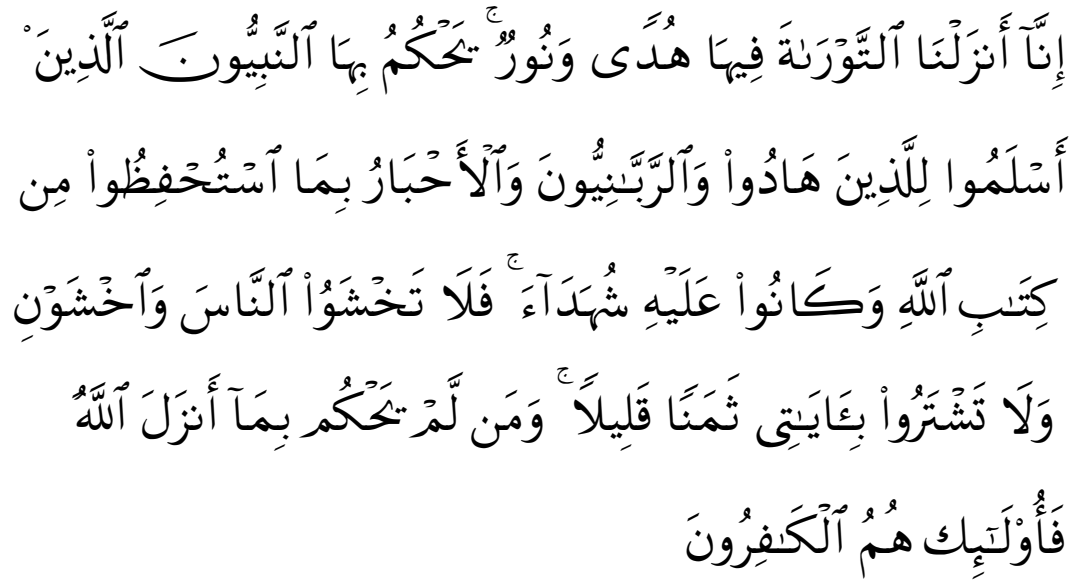

10 Muh. Abduh lahir pada tahun $1849 \mathrm{M}$ di Mesir. Ia adalah seorang putra dari pasangan Abduh Khairullah dan Junainah binti Usman al-Kabir. Lihat Ahmad Amir Aziz, Pembaruan Teologi Perspektif Modernisme Muhammad Abduh dan Neo Modernisme Fazlur Rahman (Yogyakarta: Teras, 2009), h.. 10.

11 Abdul Manan Syafi'i, "Pengaruh Tafsir Al-Manar terhadap Tafsir Al-Azhar", dalam Jurnal MIQOT, Vol. XXXVIII, No. 2, Juli-Desember 2014, h.. 267. 
Sesungguhnya Kami telah menurunkan Kitab Taurat di dalamnya (ada) petunjuk dan cahaya (yang menerangi), yang dengan Kitab itu diputuskan perkara orang-orang Yahudi oleh nabi-nabi yang menyerah diri kepada Allah, oleh orang-orang alim mereka dan pendeta-pendeta mereka, disebabkan mereka diperintahkan memelihara kitab-kitab Allah dan mereka menjadi saksi terhadapnya. Karena itu janganlah kamu takut kepada manusia, (tetapi) takutlah kepada-Ku. dan janganlah kamu menukar ayat-ayat-Ku dengan harga yang sedikit. Barangsiapa yang tidak memutuskan menurut apa yang diturunkan Allah, maka mereka itu adalah orang-orang yang kafir. ${ }^{12}$

b. QS. Al-Maidah: 45:

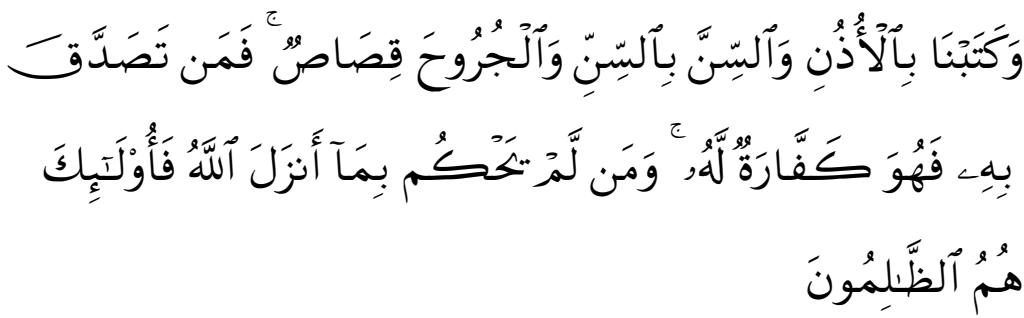

Dan Kami telah tetapkan terhadap mereka di dalamnya (AtTaurat) bahwasanya jiwa (dibalas) dengan jiwa, mata dengan mata, hidung dengan hidung, telinga dengan telinga, gigi dengan gigi, dan luka luka (pun) ada kisasnya. Barangsiapa yang melepaskan (hak kisas) nya, maka melepaskan hak itu (menjadi) penebus dosa baginya. Barangsiapa tidak memutuskan perkara menurut apa yang diturunkan Allah, maka mereka itu adalah orang-orang yang zalim. ${ }^{13}$

c. QS. Al-Maidah: 47:

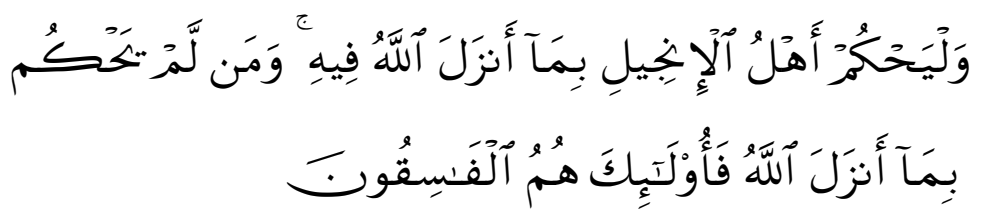

12 Departemen Agama RI, Al-Quran dan Terjemahnya (Semrang: CV ALWAAH, 1993), h. 167. 13 Ibid. 
"Dan hendaklah orang-orang pengikut Injil, memutuskan perkara menurut apa yang diturunkan Allah di dalamnya. Barangsiapa tidak memutuskan perkara menurut apa yang diturunkan Allah, maka mereka itu adalah orang-orang yang fasik". ${ }^{14}$

\section{PENAFSIRAN HAMKA TERHADAP AYAT-AYAT PENERAPAN HUKUM ALLAH}

\section{QS. Al-Maidah: 44}

HAMKA, menafsirkan QS. al-Maidah: 44 di atas dengan cara menganalisis per penggalan kalimat. Untuk ayat di atas, penggalanpenggalan kalimatnya adalah sebagai berikut:

"Sesungguhnya telah Kami turunkan Taurat". Penyaksian dari Allah sendiri bahwa Allah memang pernah menurunkan Taurat, dan berlaku Taurat itu beratus tahun lamanya, karena memang ada yang asli dari catatan Musa sendiri. Tetapi sayang terbakar atau hilang ketika Bani Israil dijajah oleh bangsa Babil dan dijadikan tawanan, sebagai dahulu telah kita terangkan.

"Di dalamnya ada petunjuk dan cahaya". Petunjuk di dalam hidup yang diridlai oleh Allah dan mengandung cahaya tauhid, menyembah Allah Yang Maha Esa, membangkitkan dan menimbulkan Bani Israil dari lembah perbudakan Fir'aun dan daripada mempersekutukan yang lain dengan Allah.

"Menghukum dengan dia Nabi-nabi yang menyerah diri (kepada Allah) terhadap orang-orang Yahudi", yaitu setelah Musa meninggal. Maka Nabi Isa Almasih sendiri pernah mengatakan, bahwa beliau adalah diutus untuk menjemput anak domba Israil yang hilang. Dari satu tokoh (titik) pun Taurat tidak akan beliau ubah. Dan Nabi-nabi itu semuanya adalah bersikap menyerah diri kepada Allah, ialah Islam. Sebab semua nabi-nabi dan rasul itu adalah putera keturunan Ibrahim belaka, yang menegakkan penyerahan diri kepada Allah. ${ }^{15}$

14 Ibid. h. 167-168.

15 HAMKA, Tafsir al-Azhar, Juz 6, cet. ke-5 (Singapura: Pustaka Nasional PTE LTD, 2003), 
Sebelum melanjutkan penafsirannya terhadap pengalan ayat berikutnya, HAMKA ingin menegaskan bahwa ajaran-ajaran yang dibawa oleh para nabi hakikatnya adalah sama, yaitu ajaran tauhid dan berserah diri kepada Allah. Penegasan HAMKA tersebut, tidak hanya didasarkan pada telaah terhadap ayat-ayat Al-Qur'an tetapi juga kajian terhadap kitab Perjanjian Lama, hal itu sebagaimana terlihat dalam paparannya di bawah ini:

Apabila kita pelajari kitab-kitab "Perjanjian Lama" catatan dari nabi-nabi Bani Israil, sejak Musa dan Harun, Yusyak sampai Yesyaya, Armiya, Daniel, Habakuk, Ezram, Nehemiya, Daud dan Sulaiman sampai kepada Ayub, Yehezekiel, Hosea, Nabi Yoel, Nabi Yunus, Nabi Amos, Nabi Mikha, Nabi Nahun, Zaganya, Nabi Rajai sampai kepada Nabi Maleakhi. Apabila kita selidiki kitab-kitab itu dengan saksama, tidaklah kita bertemu ajaran pokok mereka, selain daripada menyembah kepada Allah Yang Maha Esa dan berserah diri kepada-Nya.

Bahkan Nabi Isa Almasih (Yesus Kristus) yang didakwakan oleh Kristen sebagai Allah sejati dan manusia sejati, dan didakwakan juga Anak Allah bila kita selidiki firman-firman yang keluar dari mulut beliau sendiri di dalam kitab-kitab yang dinamai Injil Matius, Markus, dan Lukas, tidaklah pernah beliau mendakwahkan dirinya sebagai Tuhan. Kalau dia pernah mengatakan dirinya anak Allah, kitapun telah faham bahwa arti Bapa di sini adalah kasih-sayang dan perlindungan. Sebab itu bukan Isa Almasih saja anak Allah. Banyak nabi-nabi lain disebut anak Allah. Sebagai yang telah kita tuturkan ketika menafsirkan ayat 18 di atas, seketika menyatakan kesalahan Yahudi dan Nasrani yang mengakui diri mereka anak Allah.

Ajaran Isa yang keluar dari mulutnya sendiri adalah ajaran tauhid, ajaran meyerah diri kepada Tuhan Yang Maha Esa. Ketika syaitan mencoba memperdayakan dan merayu Nabi Isa; lalu kata Yesus kepadanya: "Nyahlah Engkau dari sini, hai Iblis. Karena telah tersurat hendaklah Engkau menyembah Allah Tuhanmu, dan beribadat hanya kepadaNya saja." (Matius 4;10) Maka jawab Yesus serta kepadanya: "Adalah 
tersurat; Bahwa wajiblah Engkau sujud menyembah Allah Tuhanmu, dan beribadat hanya kepada-Nya saja." (Lukas 4:8) Bahasa yang manapun kita pakai, namun di sini telah tampak bahwa Isa mengakui bahwa yang patut disembah hanya Allah! Bukan Yesus! Jangankan dikatakan Tuhan, sedangkan dikatakan Baik saja Nabi Isa keberatan: "Maka tibatiba datanglah seorang kepadanya, seraya berkata: "Ya Guru, kebajikan apakah patut hamba perbuat, supaya peroleh hidup yang kekal?” Maka jawab Yesus kepadanya: "Apakah sebabnya Engkau bertanya kepadaku darihal kebajikan?” Ada satu yang baik. Tetapi jika Engkau mau masuk kepada hidup, turutlah hukum-hukum itu." (Matius 19;16;18). "Tatkala Yesus keluar di jalan, berlari-larilah seorang datang kepadanya serta berlutut, lalu bertanya kepadanya: "Ya Guru yang baik, apakah yang patut hamba perbuat, supaya hamba menjadi waris hidup yang kekal?" Maka jawab Yesus kepadanya: "Apakah sebabnya Engkau katakan aku ini baik? Seorang pun tiada yang baik, hanya satu, yaitu Alah." (Markus 10-17;18). Demikian juga maksud dari Lukas 10-18;20.

Itulah perkataan-perkataan Isa Almasih sendiri yang dicatat oleh beberapa pengarang-pengarang Injil Matius dan Lukas."

Jelaslah, kalau diselidiki dengan seksama bahwa kepercayaan Trinitas adalah disusun kemudian. Kecintaan kepada diri beliau, kekaguman atas Mu'jizat yang dilahirkan Allah atas dirinya, menyebabkan dicarilah berbagai alasan dan dalil guna menetapkan bahwa Yesus Kristus ialah Allah. ${ }^{16}$

Setelah melakukan anlisis komparatif dengan kitab-kitab Perjanjian Lama, kemudian HAMKA melanjutkan penafsirannya terhadap penggalan ayat berikutnya, yaitu:

"Dan juga pendeta-pendeta dan orang-orang alim, dengan apa yang telah diamanati mereka dari Kitab Allah". Kita artikan kalimat Rabbani, dengan pendeta-pendeta. Arti yang asal dari Rabbani ialah orang-orang yang telah mendalam rasa ketuhanannya, telah menyediakan diri untuk Tuhan semata-mata. Kalimat pendeta berasal dari kata Sanskriet; pandit, yaitu orang-orang yang telah mendalam rasa

16 Ibid., h. 1743-1744. 
ketuhanannya pula lalu diambil ke dalam bahasa kita. Orang Melayu di Semenanjung memakainya dalam sebutan Pandita, yang berarti orang yang amat ahli, sebab itu mereka memberikan gelar Pandita Bahasa Melayu kepada Za'ba pengarang Melayu yang terkenal. Di Indonesia kita baca dengan sebutan pendeta, yang dipakai oleh kalangan Kristen untuk gelar pemimpin agama mereka. Padahal dalam Bahasa Melayu lama di Indonesia, orang alim Islampun digelari pandita. Di dalam kitab Syamsul Hidayah, karangan Ayah dan Guru penulis, Dr. Syaikh Abdulkarim Amrullah, disebutkan ulama-ulama Islam yang besar-besar itu Alim Pandita.

Ahbar, kita artikan orang alim. Maka pendeta-pendeta dan orang-orang alim Bani Israil pun meneruskan memegang amanat yang diamanatkan rasul-rasul, bilamana rasul-rasul dan nabi-nabi itu tidak ada lagi, supaya merekapun meneruskan pimpinan terhadap Bani Israil menurut Hukum Taurat, jangan dirubah-rubah.

"Dan adalah mereka itu menjadi saksi atasnya," yaitu bahwa orang tua Bani Israil yang hidup di zaman Rasulullah saw menjadi saksi atas kebenaran hal itu, tidak dapat mereka memungkirinya, karena memang demikianlah halnya. "Maka janganlah kamu takuti manusia, tetapi takutilah Aku." Nasihat kepada orang-orang Yahudi itu supaya mereka jangan takut kepada ancaman manusia dari kaum mereka sendiri, lalu berusaha menyembunyikan kebenaran Taurat. Tetapi takutlah kepada Allah, yang telah menurunkan Taurat itu untuk petunjuk dan cahaya bagi kamu. "Dan jaganlah kau juak ayat-ayat-Ku dengan harga yang sedikit." Karena mengharapkan keuntungan harta benda, lalu kamu gelapkan kebenaran, kamu perjual belikan hukum Tuhan, kamu sembunyikan hukum yang sebenarnya. Meskipun berjuta-juta uang yang kamu terima itu, namun dia masih sedikit harganya jika dibandingkan dengan kebenaran yang kamu khianati. ${ }^{17}$

Kemudian sampailah HAMKA pada penafsiran penggalan terakhir dari ayat di atas, yaitu:

17 Ibid. 
"Dan barangsiapa yang tidak menghukum dengan apa yang diturunkan Allah, maka adalah mereka itu orang-orang yang kafir.” Artinya, jika selama ini kamu mengaku memegang teguh setia kepada Taurat, hendaklah hukum yang tersebut di dalam Taurat itu kamu jalankan. Rasulullah saw sendiri di waktu diminta oleh mereka menjadi Hakim, telah mengajak mereka supaya kembali kepada Hukum Taurat. Maka pendakwaan mereka teguh setia memegang Taurat, tetapi tidak mau menjalankan hukum-hukumnya, berarti mereka kafir juga, yaitu menolak dan tidak percaya juga. ${ }^{18}$

\section{QS. Al-Maidah: 45}

Menafsirkan QS. al-Maidah: 45 di atas, HAMKA mengawalinya dengan penegasan bahwa di dalam Taurat memang ada hukumhukum/undang-undang yang berlaku pada Bani Isra'il. Hal ini menjadi sesuai dengan penggalan ayat:

"Dan telah Kami wajibkan atas mereka di dalamnya, bahwasanya jiwa (balas) dengan jiwa" Yaitu kalau seseorang membunuh satu jiwa, hendaklah digantikan dengan jiwa si pembunuh itu pula, sebagaimana yang dibayangkan pada ayat 32 di atas. "Mata dengan mata, hidung dengan hidung, gigi dengan gigi, dan luka-luka ada qisasnya. Maka barang siapa yang mendermakan hak balas itu, maka adalah itu penebus baginya." Maka tersebutlah di dalam Taurat itu bahwa siapa yang melenyapkan jiwa orang, harus diganti dengan jiwanya pula, melenyapkan mata orang, dilenyapkan pula matanya, demikian juga hidung dan gigi. Dan kalau ada perdamaian, sehingga keluarga si terbunuh atau yang kehilangan mata, hidung dan gigi itu mendermakan hak balas, artinya memberi maaf, maka kemaafan itu sudahlah sebagai kaffarat untuk menghapuskan kesalahannya;

"Dan barangsiapa yang tidak menghukum dengan apa yang diturunkan Allah, maka mereka itu adalah orang-orang yang aniaya." Zalim dan aniayalah orang yang tidak menjalankan hukum yang telah ditentukan Allah itu. Zalimlah orang yang mengaku dirinya berpedoman kepada Taurat, padahal hukum Taurat tidak dijalankan. ${ }^{19}$

18 Ibid.

19 Ibid. h. 1745. 
Setelah menafsirkan penggalan-penggalan ayat di atas, HAMKA kemudian sedikit menambahi kutipan beberapa fasal dari kitab Taurat. Hal ini dimaksudkan sebagai penguat atau bahkan sebagai bukti bahwa apa yang dinyatakan oleh QS. al-Maidah: 45 di atas adalah cocok (memang begitu adanya) seperti halnya yang ada dalam kitab Taurat. HAMKA menyatakan:

Dalam Taurat yang beredar sekarang pun memang bertemu tertulis hukum-hukum itu, yang tersebut di dalam "Kitab Keluaran" Fasal 21: 23 -Tetapi jikalau ada bahaya kematian sertanya, maka tak akan jangan jiwa akan diganti jiwa. 24 -Maka akan ganti mata, gigi akan ganti gigi, tangan akan ganti tangan, kaki akan ganti kaki. 25 -Keturunan akan ganti keturunan, luka kaan ganti luka, bincut akan ganti bincut.

Di dalam kitab "Imamat Orang Lewi" Fasal 24 ayat 17 tersebut pula: "Maka barangsiapa yang telah memalu orang sampai mati, tak akan jangan ia pun akan mati dibunuh."20

\section{QS. Al-Maidah: 47}

Masih berhubungan dengan dua ayat sebelum, ayat ini juga berbicara tentang ahli kitab. Oleh karena itu, dalam menafsirkan ayat ini HAMKA banyak memberi keterangan tambahan menyangkut kelompok tersebut. HAMKA memulai dengan penggalan”

"Maka hendaklah menghukum Ahlul Injil dengan apa yang telah diturunkan oleh Allah padanya." Sudah sama diketahui pendirian Islam tentang Ahlul-Kitab. Meskipun pokok kepercayaan mereka menurut keyakinan Islam sudah jauh melampaui batas yang ditentukan Allah, sudah Ghuluw, yaitu berlebih-lebihan, namun mereka tidaklah dikerasi dan dipaksa masuk Islam. Tetapi kalau hendak tetap memegang Injil, peganglah Injil yang betul, hilangkanlah pengaruh lain dan tafsiran lain yang dimasukkan ke dalam Injil oleh keputusan Pendeta. Melainkan jalankanlah hukumnya benar-benar.

20 Ibid. 
"Dan barangsiapa yang tidak menghukum dengan apa yang diturunkan oleh Allah, maka itulah orang-orang yang fasik." Ayat ini dan ayat sebelumnya memberikan kejelasan yang nyata sekali, bahwa di dalam kekuasaan Islam, orang-orang Dzimmi Yahudi dan Nasrani diperintahkan menjalankan hukum menurut kitab mereka. Padahal isi Hukum Tuhan dalam semua kitab suci, baik Taurat dan Injil, sampai kepada Al-Quran dasarnya ialah satu, yaitu Hukum Tuhan. ${ }^{21}$

Sekali lagi, dalam tafsirnya tentang QS. al-Maidah: 47 ini, HAMKA banyak memberi ulasan tambahan menyangkut Ahli Kitab. Ulasan tambahannya ini sekaligus juga menggambarkan pemikiran dan pandangan beliau -sebagai orang Islam Indonesia- terhadap kelompok tersebut. Berikut ini adalah kutipan dari sebagian ulasannya:

Di zaman hidupnya Almasih, oleh karena kekuasaan adalah pada bangsa Romawi dan kaum Yahudi dalam jajahan belumlah boleh dapat menjalankan Hukum Tuhan dari Taurat dengan tegas. Beliau hanya berkata: "Berikanlah hak Allah kepada Allah dan hak Kaisar kepada Kaisar." Malahan seketika orang-orang Yahudi datang kepada beliau membawa seorang perempuan yang mereka tuduh berzina, supaya dijalankan kepadanya Hukum Taurat, beliau bertanya bahwa adakah di antara mereka itu orang-orang yang tidak pernah berdosa? Siapa orangorang yang tidak pernah berdosa itulah yang melontarkan perempuan itu dengan batu sampai mati. Maka berpandang-pandanglah satu dengan yang lain, dan tidak ada seorang jua pun yang berani menjatuhkan hukum kepada perempuan itu, sebab merasa bahwa diri masing-masing tidak sunyi daripada bersalah. Dengan sikap Almasih yang demikian, bukan berarti bahwa beliau mengubah Hukum Taurat, melainkan menyuruh mereka terlebuh dahulu membersihkan jiwa sendiri sebelum menuduh-nuduh orang lain. Dan yang lebih beliau dari pihak penguasa Romawi. Sebab hak menghukum mesti dijalankan dalam kekuasaan pemerintahan Romawi.

Kemudian setelah 300 tahun beliau meninggalkan dunia, barulah Kristen diakui sebagai agama resmi oleh Kerajaan Romawi. Tetapi Kekaisaran

21 Ibid. h.1747. 
Romawi hanya menerima Kristen sebagai anutan kepercayaan yang telah banyak diadakan perubahan pula, terkhusus sebagai anutan kepercayaan Trimurti. Adapun dalam hal Hukum, tidaklah Romawi mengambil dari Taurat, tetapi khusus dari pusaka Fiqh Yunani, yang dilanjutkan oleh Fiqh hukum Romawi. Kadang-kadang hasil karya Cicero dan lain-lain, itulah undang-undang yang berkembang dan berlaku, sedang Hukum dan Undang-undang Allah tidaklah diberi peluang untuk dijadikan dasar hukum pidana dan perdata.

Maka dapatlah kami fahami, demi melihat ayat-ayat ini bahwa hanya Islam yang memberikan jaminan tegas kepada pemeluk Yahudi dan Nasrani, bahwa kalau mereka tidak mau masuk Islam, sebagai Ahlul Kitab, biarlah mereka tetap memegang agama dan kitab mereka. Mereka adalah Dzimmi, yaitu dalam perlindungan pemerintahan dan kekuasaan Islam. Tetapi hendaklah mereka betul-betul menjalankan hukum yang asli dari kedua kitab itu. Taurat dan Injil. Ayat-ayat ini bukanlah mengatakan bahwa Yahudi dan Nasrani boleh menjalankan hukum mereka, tetapi mereka diwajibkan menjalankan hukum itu dalam pemerintahan Islam. Sebab itu pemerintahan Islam melakukan juga pengawasan, adakah kedua Ahlul Kitab itu menjalankan hukum agamanya atau tidak. ${ }^{22}$

Kemudian di akhir ulasannya, HAMKA juga memberikan semacam closing statement menyangkut objek (audiens) dari ketiga ayat di atas; apakah audiens-nya hanya untuk Ahli Kitab atau juga berlaku untuk umat Islam. Sekaligus HAMKA juga memberikan pemikirannya tentang sikap yang sebaiknya dilakukan umat Islam dalam mengamalkan ayat tersebut. Berikut ini adalah pernyataan beliau:

Tentang ketiga ayat ini banyaklah pula perbincangan ahli tafsir, apakah dia hanya terkhusus sebagai ancaman kepada Yahudi dan Nasrani, ataukah mengenai juga kita Kaum Muslimin? Ada dibawakan orang tafsir yang mereka katakan diriwayatka dari Ibnu Abbas, bahwa beliau berkata: "Kafir di sini bukanlah mencapai kafir, dan zalim bukanlah mencapai zalim, dan fasik bukanlah mencapai fasik. 
Dan ada riwayat Ibnu Abbas juga, katanya ayat-ayat ini hanya mengenai Bani Iarail. Mendengar itu berkatalah Hudzaifah: "Enak benar bagimu ada kawan Bani Israil, kalau segala yang manis hanya untukmu dan segala yang pahit hanya untuk Bani Israil. Sungguh, demi Allah, kamu akan menempuh pula jalan mereka menurut jejak langkah mereka."

Dan satu riwayat lain dari Ibnu Abbas yang diriwayatkan oleh Ibnul Mundzir: "Sebaik-baik kaumlah rupanya kamu ini kalau segala yang manishanya untuk kamu dan segala yang pahit buat Ahlul Kitab." Dan ditanyakan orang kepada Sa'id bin Jubair ke mana tujuan ketiga ayat. "Barangsiapa yang yang tidak menghukum dengan apa yang diturunkan oleh Allah" itu apa benarkah tertuju kepada Bani Israil saja? Beliau menjawab: "Tidak! Bahkan dia diturunkan atas kita."

Riwayat yang diterima dari Maqaam, Maula Ibnu Abbas pun menyatakan demikian pula, bahwa ayat ini diturunkan kepada Ahlul Kitab dan kepada kita Kaum Muslimin. Cuma tambahannya ialah bahwa kafir di sini bukanlah mencapai kafir syirik, dan Zhulm di sini pun bukan mencapai zhulm syirik, dan fasik di sini pun bukan mencapai fasik syirik.

Kita pun dapatlah memahamkan bahwa ayat Al-Quran, diturunkan kepada Nabi kita Muhammad saw meskipun tertuju kadang-kadang kepada Ahlul Kitab, bukanlah dia semata-mata suatu kisah yang akan kita baca saja, tetapi adalah dia untuk kita ambil banding. Sebagai Muslimin janganlah kita melalaikan menjalankan Hukum Allah. Sebab di awal surat sendiri, yang mula-mula diberi peringatan kepada kita ialah supaya menyempurnakan segala 'Uqud yang terpenting di antara kita dengan Allah.

Selama kita hidup, selama iman masih mengalir di seluruh pipa darah kita, tidaklah sekali-kali boleh kita melepaskan cita-cita agar Hukum Allah tegak di dalam alam ini, walaupun di negeri mana kita tinggal. Moga-moga tercapai sekedar apa yang dapat kita capai. Karena Tuhan tidaklah memikulkan kepada kita suatu beban yang melebihi dari tenaga kita. Kalau Hukum Allah belum jalan, janganlah kita berputus asa. Dan kufur, zhulm, dan fasiklah kita kalau kita percaya bahwa ada hukum lain yang lebih baik daripada Hukum Allah. 
Dan jika kita yang berjuang menegakkan cita Islam ditanya orang: "Adakah kamu, hai Ummat Islam bercita-cita, berideologi, jika kamu memegang kekuasaan, akan menjalankan hukum Syariat Islam dalam negara yang kamu kuaisai itu?" Janganlah berbohong dan mengolokolokkan jawaban. Katakan terus terang bahwa cita-cita kami memang itu. Memang hendaknya berjalan Hukum Allah dalam negara yang yang kita kuasai itu. Apa artinya kita kalau cita-cita yang telah digariskan Tuhan dalam Al-Quran itu kita pungkiri?"

Jawablah tegas: "Memang akan kami paksa mereka menuruti Hukum Islam. Dan setengah dari Hukum Islam terhadap golongan pemeluk agama minoritas itu ialah agar supaya mereka menjalankan Hukum Taurat, Ahli Injil diwajibkan menjalankan menjalankan Hukum Injil. Dan kita boleh membuat Undang-undang menurut teknik pembikinannya, memakai fasal-fasal dan ayat-ayat suci, tapi dasarnya wajiblah Hukum Allah dari kitab-kitab suci, bukan hukum buatan manusia atau diktator manusia," Katakan itu terus terang dan jangan takut...

Apabila kita membicarakan Hukum Allah, hendaklah kita menilik terlebih dahulu kepada Filsafat Hukumnya dan dari mana sumber Hukum. Dalam Islam sudah nyata bahwa sumber Hukum ialah Allah dan Rasul, atau Al-Quran dan Sunnah. Sebab itu dalam Islam manusia bukanlah pencipta Hukum melainkan pelaksana Hukum Tuhan. Tetapi manusia tadi diberi kebebasan pula berijtihad, bagaimana supaya Hukum Tuhan itu berjalan. Pokok Hukum Tuhan dan Rasul itu disimpulkan dalam bunyi ayat: "Menghalalkan bagi kamu akan yang baik-baik dan mengharamkan atas kamu barang yang buruk." Dan mengambil manfaat dan menolak mudharat...

Kalau kita tilik pula keadaan bertumbuhnya Republik Indonesia. Secara hukum kita dapat mengatakan bahwa selain dari negara ini suatu negara Negara Kesatuan, dia pun adalah Negara yang didirikan atas persetujuan golongan-golongan yang terbesar di dalam negeri ini pada hari bulan Juli 1945, yang dikenal dengan nama Jakarta Charter, yaitu golongan Islam, Nasionalis dan Kristen. Pemuka yang mengikat perjanjian itu mempunyai cukup syarat-syarat buat disebut "Ahlul Halli wal 'Aqdi". Isi perjanjian ialah akan mendirikan sebuah negara yang semua golongan 
terjamin menganut kepercayaannya; malahan pernah ditegaskan bahwa bagi pemeluk Islam supaya menjalankan syariat agamanya.

Maka negara kita telah dibentuk atas dasar janji bersama, atau 'Uqud; yang telah diperintahkan kepada orang-orang yang beriman supaya menyempurnakannya. Menurut pangkal Surat al-Maidah ini, perjanjian ini wajiblah dipelihara dan disempurnakan, karena dia bukanlah menghalalkan yang haram dan mengharamkan yang halal. Bahkan pada adatnya, kalau tidaklah ada Charter ini, tidaklah akan tercapai kemerdekaan yang telah ada ini. Maka dalam Negara yang telah ada ini, wajib jugalah sarjana-sarjana dan ahli-ahli fikir Islam berjuang sekedar tenaganya, agar Hukum Tuhan itu berjalan, dengan teratur dan diterima oleh masyarakat umum, melalui kemungkinankemungkinan yang ada. Karena kitapun tahu bahwasanya untuk mencapai suatu cita-cita yang sah dan luhur, wajib juga kita mempertimbangkan ruang dan waktu. Dan tidaklah kita diberi beban oleh Allah melebihi daripada tenaga dan kemampuan yang ada pada kita. Sebab pekerjaan membentuk undang-undang dari sebuah negara yang telah didirikan dengan kesepakatan segala golongan itu, padahal negara itu dahulunya bekas jajahan, bukanlah semudah apa yang dikhayalkan oleh fikiran. ${ }^{23}$

\section{KONSTRUKSI PENAFSIRAN HAMKA TENTANG PENERAPAN HUKUM ALLAH}

Berdasarkan deskripsi tentang penafsiran HAMKA terhadap QS. Al-Maidah: 44, 45, dan 47 di atas, maka penafsiran HAMKA tentang penerapan hukum Allah secara sederhana dapat dikonstruksikan sebagai berikut:

HAMKA, berdasarkan kajiannya terhadap ayat-ayat penerapan hukum Allah, menyatakan bahwa para ahli tafsir banyak mempertanyakan; apakah ayat-ayat yang berbicara tentang

23 Ibid., h. 1750-1758. 
penerapan hukum Allah tersebut hanya berlaku untuk umat Yahudi dan Nasrani, ataukah juga berlaku untuk umat Islam, mengingat objek pembicaraan pada ayat-ayat tersebut adalah ahl al-Taurät dan ahl al-Injīi?

Dalam rangka menelusuri jawaban dari pertanyaan tersebut, HAMKA mengutip beberapa riwayat yang dikemukakan oleh para ulama tafsir. Di antaranya adalah riwayat yang diterima dari Maqaam, Maula Ibnu Abbas, ia menyatakan bahwa ayat-ayat tersebut diturunkan kepada Ahlul Kitab dan sekaligus juga kepada umat Islam. Hanya saja ia menambahkan bahwa ancaman label kafir, zalim, dan fasik pada penggalan terakhir ayat-ayat tersebut tidak lah mencapai derajat kafir syirik, zalim syirik, dan juga fasik syirik.

Lebih jauh, HAMKA menyatakan bahwa jawaban di atas sangat masuk akal, mengingat Al-Qur'an adalah Kitab Suci yang diturunkan kepada Nabi Muhammad dan karenanya ia juga ditujukan kepada umat Islam, sekalipun di dalamnya ada ayat-ayat ditujukan kepada Ahlul Kitab. Seperti halnya ayat-ayat tentang penerapan hukum Allah (yang menjadi objek bahasan penelitian ini). Ayat-ayat tersebut sekalipun ditujukan ahli kitab, namun hal itu supaya menjadi bahan perbandingan umat Islam agar tidak lalai menjalankan hukum Allah sebagaimana umat Yahudi dan Nasrani waktu itu.

Selanjutnya, oleh karena sudah jelas bahwa ayat-ayat tentang penerapan hukum Allah itu juga ditujukan kepada umat Islam, maka dengan tegas HAMKA menyatakan bahwa umat Islam wajib menjalankan (menerapkan) hukum Allah. Hal ini, sebagaimana pernyataannya: "Selama kita hidup, selama iman masih mengalir di seluruh pipa darah kita, tidaklah sekali-kali boleh kita melepaskan citacita agar Hukum Allah tegak di dalam alam ini, walaupun di negeri mana kita tinggal. Moga-moga tercapai sekedar apa yang dapat kita capai...", "Dan jika kita yang berjuang menegakkan cita Islam ditanya orang: "Adakah kamu, hai Ummat Islam bercita-cita, berideologi, 
jika kamu memegang kekuasaan, akan menjalankan hukum Syariat Islam dalam negara yang kamu kuaisai itu?" Janganlah berbohong dan mengolok-olokkan jawaban. Katakan terus terang bahwa cita-cita kami memang itu. Memang hendaknya berjalan Hukum Allah dalam negara yang yang kita kuasai itu. Apa artinya kita kalau cita-cita yang telah digariskan Tuhan dalam Al-Quran itu kita pungkiri? Jawablah tegas: "Memang akan kami paksa mereka menuruti Hukum Islam. Dan setengah dari Hukum Islam terhadap golongan pemeluk agama minoritas itu ialah agar supaya mereka menjalankan Hukum Taurat, Ahli Injil diwajibkan menjalankan menjalankan Hukum Injil. ${ }^{24}$

Namun demikian, HAMKA mewanti-wanti bahwa dalam menerapkan hukum Allah, umat Islam harus terlebih dahulu memahami filsafat hukumnya (h\{ikmat al-tasyri>'). Hal ini dimaksudkan agar umat Islam dalam menerapkan hukum Allah tersebut tidak secara 'apa adanya', melainkan disesuaikan situasi dan kondisi yang ada dengan tetap mempertimbangkan aspek maqa $>$ s $\}$ id-nya. Dalam hal ini, HAMKA menyimpulkan bahwa pokok hukum Allah (maqa $>$ s $\}$ id) itu teringkas dalam spirit "menghalalkan yang Allah halalkan dan mengharamkan yang Allah haramkan" dan spirit "mengambil manfaat dan menolak mudharat."

Dengan ini, HAMKA mengidealkan bahwa umat Islam harusnya memang menerapkan hukum Islam, apalagi kalau hal itu mengacu pada bentuk-bentuk negara seperti yang diklasifikasikan oleh ulama fikih, seperti negara Islam, negara kafir, dan negara perang. Akan tetapi, karena perkembangan modernitas yang ada, bentuk-bentuk negara tidak lagi mengacu pada klasifikasi ulama fikih di atas, melainkan berbentuk negara bangsa, maka hukum yang digunakan pun bukan hukum Islam tetapi undang-undang hasil kesepakatan bersama. Dalam konteks negara bangsa seperti ini menurut HAMKA umat Islam tidak lagi dalam kondisi ideal, karenanya mereka boleh mengamalkan 
hukum negara asalkan sesuai dengan kedua prinsip di atas, yaitu "menghalalkan yang Allah halalkan dan mengharamkan yang Allah haramkan" dan "mengambil manfaat dan menolak mudharat."

Contohnya negara Indonesia. Bentuk negara Indonesia bukan lah negara Islam, sekalipun mayoritas penduduknya beragama Islam. Bentuk negara Indonesia adalah Negara Kesatuan Republik Indonesia. Negara ini didirikan atas kesepakatan seluruh elemen bangsa yang dituangkan dalam Piagam Jakarta pada bulan Juli 1945. Di antara isi pokok dari Piagam Jakarta tersebut adalah didirikannya sebuah negara yang menjamin seluruh elemen anak bangsa untuk menjalankan agama dan kepercayaannya masing-masing.

Menurut HAMKA, Piagam Jakarta dengan isi pokoknya seperti di atas adalah tidak bertentangan dengan prinsip hukum Allah, yaitu menghalalkan yang baik dan mengharamkan yang buruk. Bahkan, kalau tidak ada kesepakatan sebagaimana tertuang pada Piagam Jakarta tersebut, kemungkinan besar tidak akan terwujud kemerdekaan, dan kalau tidak terwujud kemerdekaan tentu tidak ada Negara Kesatuan Republik Indonesia. Keadaan seperti ini jelas nilai madharatnya lebih besar daripada manfaatnya. Dengan ini, Piagam Jakarta juga sesuai dengan prinsip hukum Allah, yaitu menolak bahaya dan mengambil manfaat.

Dari semua paparan di atas, dapat diambil kesimpulan bahwa ayatayat penerapan hukum Allah oleh HAMKA harus dipahami dengan melihat situasi dan kondisi yang ada; jika umat Islam ada dalam bentuk negara Islam ( $D a>r$ al-Isla $>m$ ), maka wujud penerapannya adalah dengan menjadikan hukum Allah sebagai hukum negara, akan tetapi jika bentuk negara bukan negara Islam, tetapi negara bangsa seperti Indonesia, maka bentuk penerapan hukum Allah adalah dengan spirit filsafat hukumnya, yaitu "menghalalkan yang Allah halalkan dan

25 Ibid., h. 1751. 
mengharamkan yang Allah haramkan" dan "mengambil manfaat dan menolak mudharat.” Adapun teknik dan bentuk hukum negara tersebut diserahkan pada kesepakatan semua elemen anak bangsa melalui perwakilan-perwakilan yang duduk dalam sebuah lembaga yang dalam Islam disebut dengan Ahl al-H\}alli wa al-Aqdi.

\section{PRIBUMISASI ISLAM DALAM TAFSIR AL-AZHAR}

Teori pribumisasi Islam ini dicetuskan oleh cendikiawan muslim asal Indonesia, yaitu Abdurrahman Wahid, atau akrab dipanggil dengan Gus Dur. ${ }^{26}$ Teori ini bertumpu pada tiga tema besar, yaitu; universalisme Islam, kosmopolitanisme Islam, dan pribumisasi Islam. Universalisme Islam adalah gagasan tentang Islam sebagai agama universal, yang universlitasnya ada pada berbagai manifestasi ajaranajarannya (pemisahan antara lokalitas Arab dengan prinsip-prinsip pokok Islam). Kosmopolitanisme Islam adalah gagasan tentang keterbukaan Islam terhadap peradaban lainnya, atau dengan kata lain adalah gagasan tentang dialog antara Islam (ajaran) dengan lokalitas lain, dalam konteks ini adalah antara Islam dengan lokalitas Indonesia. Dengan ini, pokok-pokok Islam yang telah dipisahkan dari budaya Arab, kemudian didialogkan dengan lokalitas lain, untuk kemudian saling berintegrasi, sehingga terjadilah Islam dengan tampilan lokalitas lain tersebut. Pribumisasi Islam adalah gagasan tentang manifestasi dari (hasil) dialog antara ajaran Islam dengan lokalitas lain, yang dalam konteks ini adalah Indonesia (pembumian Islam dalam konteks lokal Indonesia $)^{27}$. Teori ini akan dipakai untuk menganalisis bentuk

26Abdurrahman Wahid (Gus Dur) adalah salah seorang cucu dari pendiri ormas terbesar di Indonesia -Nahdlatul Ulama (Nu), yaitu Kyai Haji Hasyim Asy’ari. Bapaknya bernama Wahid Hasyim dan ibunya bernama Nyai Solechah (putri sulung dari KH. Bishri Syamsuri -Rais Am ketiga Nu). Gusdur dikenal sebagai tokoh pluralism Indonesia. Pemikiranpemikirannya banyak menginspirasi orang tentang berislam secara moderat dan santun. Di antara pemikirannya tersebut adalah, gagasan tentang nalar pribumi Islam.

27 Dikutip dari Aksin Wijaya, Menusantarakan Islam (Yogyakarta: Nadi Pustaka, 2011), h.. 
pribumisasi Islam dalam Tafsir Al-Azhar, khususnya berkaitan dengan tafsir ayat-ayat penerapan hukum Allah.

Berdasarkan paparan konstruksi penafsiran HAMKA terhadap ayat-ayat penerapan hukum Allah di atas, jelas bahwa HAMKA sebagai seorang muslim Indonesia begitu serius dalam mendialogkan dua realitas, yaitu realitas Islam dan realitas Indonesia. Sebagai seorang muslim, idealnya hukum-hukum Islam lah yang harus ditegakkan. QS. Al-Maidah ayat 44, 45, dan 47 begitu jelas dan tegas mengecam mereka yang tidak berhukum dengan hukum-hukum Allah adalah kafir, zalim, dan fasik. Akan tetapi, sebagai seorang warga negara Indonesia, tentu hukum-hukum negara lah yan harus dilaksanakan. Sekali lagi, dua realitas inilah yang didialogkan oleh HAMKA sehingga sampailah ia pada pemikiran yang penulis simpulkan sebagai berikut:

Dalam keadaan ideal, umat Islam wajib menerapkan hukumhukum Allah. Keadaan ideal yang dimaksud adalah terbentuknya negara Islam, karena hanya dalam negara Islam lah, umat Islam bisa menerapkan hukum-hukum Allah secara totalitas. Sedang dalam keadaan yang tidak ideal, umat Islam tidak dituntut untuk menerapkan hukum-hukum Allah secara totalitas, karena hal itu di luar batas kemampuannya, dan Allah tidak membebani hamba-Nya kecuali sebatas kemampuannya. Negara Indonesia yang berbentuk negara bangsa (Pancasila sebagai dasar Negara dan UUD 1945 sebagai dasar hukumnya) adalah bukan bentuk negara yang ideal untuk diterapkannya hukum Allah. Dalam keadaan seperti ini, umat Islam Indonesia mendapat pemakluman jika tidak bisa menerapkan hukumhukum Allah secara maksimal. Namun demikian, jika umat Islam tidak bisa menerapkan hukum Islam secara formal karena keadaan (bentuk) negara yang tidak ideal, bukan berarti umat Islam Indonesia tidak melaksanakannya sama sekali. Mereka tetap dituntut untuk menerapkan hukum-hukum Allah, hanya saja dari bentuknya yang 
formal menjadi bentuk 'spirit/ruh' (maqashid)-nya. Dalam konteks ini, secara spirit (maqashid) hukum Islam adalah "menghalalkan yang baik-mengharamkan yang buruk, dan mengambil manfaat-menolak mudharat". Dengan kata lain, HAMKA di satu sisi menganggap bahwa bentuk negara Indonesia seperti ini belum ideal (final) untuk umat Islam, bentuk negara ideal untuk umat Islam adalah negara Islam, di mana di dalamnya bisa diterapkan hukum-hukum Allah secara maksimal (kaffah), namun di sisi lain HAMKA menganggap bahwa bantuk negara ini sebagai bentuk terbaik untuk bangsa Indonesia, karena dengan bentuk negara seperti ini dapat terwujud pesatuan dan kesatuan bangsa. Oleh karenanya, HAMKA menerima bentuk Negara Kesatuan Republik Indonesia dan segala hukum/perundangan yang berlaku di dalamnya, karena bentuk NKRI tidak bertentangan dengan maqashid hukum Allah di atas.

\section{KESIMPULAN}

Berdasarkan telaah dan kajian di atas, diperoleh satu pemahaman bahwa pribumisasi Islam (baca: al-Qur'an) adalah hal yang niscaya, dan untuk melakukan itu setiap penafsir harus mampu memahami konteks turunnya ayat (dalam rangka menyarikan universalitas Islam) dan juga konteks lokalitas kekinian penafsir dan masyarakatnya (dalam rangka merumuskan format aplikasinya), untuk kemudian mendialogkan keduanya, sehingga antara Islam dan Indonesia akan senantiasa berintegrasi secara positif. HAMKA (seorang muslim Indonesia) adalah salah satu dari tokoh tersebut, penafsirannya terhadap ayat-ayat penerapan hukum Allah kiranya bisa menjadi salah satu role model bagi umat Islam Indonesia untuk ber-Islam sealigus ber-Indonesia yang baik. Bahkan penafsirannya tersebut juga bisa menjadi inspirasi umat Islam dunia untuk selalu bisa mendialogkan antara agama dan negara. 


\section{DAFTAR PUSTAKA}

Aziz, Ahmad Amir, Pembaruan Teologi Perspektif Modernisme Muhammad Abduh dan Neo Modernisme Fazlur Rahman, Yogyakarta: Teras, 2009.

Departemen Agama RI, Al-Quran dan Terjemahnya, Semrang: CV ALWAAH, 1993

Dewan Redaksi Ensiklopedi Islam, EnsIklopedi Islam, Jakarta: Ichtiar Baru Van Hoeve, 1993.

HAMKA, Doktrin Islam yang Menimbulkan Keberanian dan Kemerdekaan, t.kp.: tp. 1985.

--------, Kenang-kenangan Hidup, Jakarta: Bulan Bintang, 1979.

-----------, Tafsir al-Azhar, Juz 6, cet. ke-5, Singapura: Pustaka Nasional PTE LTD, 2003.

Noer, Deliar, Gerakan Modern di Indonesia 1900-1942, Jakarta:LP3ES,1981.

Roziqin, Baidatul, 101 Jejak Tokoh Islam Indonesia, Yogyakarta: e-Nusantara, 2009.

Syafi'I, Abdul Manan, “Pengaruh Tafsir al-Manar Terhadap Tafsir AlAzhar”, Jurnal MIQAT, Vol. XXXVIII, NO. 2 Juli-Desember 2014. Wijaya, Aksin, Menusantarakan Islam, Yogyakarta: Nadi Pustaka, 2011. 